\title{
Anisotropy Influence in Obtaining Stiffness Property in Bending of Brazilian Wood Species
}

\author{
Francisco Antonio Rocco Lahr ${ }^{1}$, André Luis Christoforo ${ }^{2, *}$, Tulio Hallak Panzera ${ }^{3}$, \\ Diogo Aparecido Lopes Silva ${ }^{4}$, Decio Gonçalves ${ }^{5}$
}

\author{
${ }^{1}$ Department of Structural Engineering, Engineering School of São Carlos (EESC/USP), São Carlos, 13566-590, Brazil \\ ${ }^{2}$ Centre for Innovation and Technology in Composites - CITeC, Department of Civil Engineering, São Carlos Federal University, \\ São Carlos, 13565-905, Brazil \\ ${ }^{3}$ Centre for Innovation and Technology in Composites - CITeC, Department of Mechanical Engineering, Federal University of São João \\ del-Rei, São João del-Rei, 36307-352, Brazil \\ ${ }^{4}$ Department of Production Engineering, Engineering School of São Carlos (EESC/USP), São Carlos, 13566-590, Brazil \\ ${ }^{5}$ Department of Civil Engineering, University of Franca (UNIFRAN), Franca, 14404-600, Brazil
}

\begin{abstract}
The design of timber structures, and other materials, must follow the procedures and methods of calculation of normative standards. Some normative documents in the design of timber structures adopt quite simple arithmetical relationships to relate wood properties in order to make it simple and quick evaluation of the behavior of structural elements, as is the specific case of Brazilian standard ABNT NBR 7190:1997, establishing a single relation for the shear (G) and the longitudinal (E) modulus of elasticity $[\mathrm{E}=\mathrm{G} / 20]$, which implies taking statistical equivalence to the values of the elastic moduli in the longitudinal-radial $\left(\mathrm{G}_{\mathrm{LR}}\right)$ and longitudinal-tangential $\left(\mathrm{G}_{\mathrm{LT}}\right)$ directions, which are important properties in relation to the requirements of structural projects. In this context, this study aimed to investigate, with the aid of four and three points static bending tests performed on the of dicotyledonous wood species grown in Brazil, the determination of the values of $E_{L R}, E_{L T}, G_{L R}$ and $G_{L T}$ to confirm the possibility of its equivalence ( $E_{L R}$ and $E_{L T}, G_{L R}$ and $G_{L T}$ ), and for establishing correlations among them. The results of the hypothesis testing between the shear and longitudinal modulus of elasticity exhibited equivalent by species and simultaneously for all species, and the results of the linear regression model showed not possible to estimate the shear modulus of elasticity with knowledge of the longitudinal modulus of elasticity, and the optimal coefficient found by least squares method to the relation between the modulus of elasticity was equal to 35 ( $\mathrm{E}=\mathrm{G} / 35$ ), suggesting the need for an adjustment of the coefficient for this scale more safe wooden structures.
\end{abstract}

Keywords Wood, Modulus of elasticity, Bending, Anisotropy

\section{Introduction}

Improve design quality of building wooden elements and of timber structures is a goal that must be systematically sought by professionals working in the area.

One of the main topics that can compete directly for this to be achieved is related to a deeper knowledge of strength and stiffness wood properties.

Some normative standards in this subject adopt simple arithmetic relationships to relate wood properties in order to make simple and quick the evaluation of structural elements behavior. In the specific case of the Brazilian Standard ABNT NBR 7190:1997, some relations between longitudinal modulus of elasticity (E) and shear modulus $(\mathrm{G})$ in wood are adopted, but without appropriate experimental

* Corresponding author:

alchristoforo@yahoo.com.br (André Luis Christoforo)

Published online at http://journal.sapub.org/ijme

Copyright (C) 2014 Scientific \& Academic Publishing. All Rights Reserved basis. This can induce to doubts in engineering design and someone can take calculation assumptions that lead to overestimation of bars, resulting increase in structures cost, as asserted by Mateus [1], Karlsen [2]; Bodig and Jayne [3]; Ritter [4]; Calil et al. [5].

To know the longitudinal and the shear modulus of elasticity is essential for correct evaluation of plate structures performance, for example, according to authors as Herzog et al. [6]; Christoforo et al. [7], Ferro et al. [8], Icimoto et al. [9], Braz et al. [10] among others.

Several studies have been conducted to establish the theoretical basis aiming to determine shear modulus in wood, considering its features of orthotropy, being mentioned among them Price [11]; Schniewind [12], Gilles [13]; Holmberg, Persson, Petersson [14] and Nairn [15]. Each authors, with their specificities, have contributed to better understanding of the problem.

Researchers like Ballarin and Nogueira [16]; Mascia and Rocco Lahr [17] sought to obtain experimental values of G, although working mostly with small number of specimens, 
aspect that prevent generalization of the results obtained.

Christoforo et al.[18] presented an analytical methodology for determination the longitudinal and shear moduli of structural lumber, using the three-point static bending tests (adapted from Brazilian Standard ABNT NBR 7190 [19]), based on methodology recommended by Rocco Lahr [20]. Wood species used in these trials were Pinus elliottii and Corymbia citriodora. The related equations were developed according to virtual forces method and the shear shape coefficient $\left(f_{s}\right)$ to rectangular cross section was adopted as $1.20(6 / 5)$. Results of coefficients $(\alpha)$ between moduli $(\mathrm{E}=\alpha \cdot \mathrm{G})$ for the referred wood species were, respectively, 18.70 and 21.20 , very close to the coefficient (20) set by Brazilian Standard ABNT NBR 7190 [19].

On the other hand, evaluations of strength and stiffness wood properties by non-destructive testing are becoming more frequent. Papers authored by Bucur and Archer [21], Sandoz [22], Ross, Brashaw and Pellerin [23]; Gonzales, Valle and Costa [24], Yang et al. [25]; Gonçalves, Trinca and Cerri [26], Alves and Carrasco [27], are some examples. However, often results constitute estimates based on correlation between parameters, with high variability among results.

For simplicity, it has been usual to adopt statistical equivalence for values of $\mathrm{G}$ in the longitudinal-radial $\left(\mathrm{G}_{\mathrm{LR}}\right)$ and longitudinal-transversal $\left(\mathrm{G}_{\mathrm{LT}}\right)$ directions, important parameters related to structural design requirements, as evidenced by Gilles [13] and Green et al. [28], among others. Similar position is taken by the ABNT NBR7190 [19], that establishes a unique relationship between these properties, i.e., $\mathrm{E}=\mathrm{G} / 20$.

In this context, this work focuses on determining values of $\mathrm{E}_{\mathrm{LR}}, \mathrm{E}_{\mathrm{LT}}, \mathrm{G}_{\mathrm{LR}}$ and $\mathrm{G}_{\mathrm{LT}}$, based on static bending tests (detailed in next items), to some dicotyledonous species grown in Brazil, aiming to confirm the possibility of consider its equivalence $\left(\mathrm{E}_{\mathrm{LR}}\right.$ and $\mathrm{E}_{\mathrm{LT}} ; \mathrm{G}_{\mathrm{LR}}$ and $\left.\mathrm{G}_{\mathrm{LT}}\right)$, and establish proper correlations.

\section{Material and Methods}

To achieve the proposed objective, five hardwood species were considered, each one representing a strength class, according to establishes ABNT NBR 7190 [19]:

- Cedinho (Erisma uncinatum), Class C20;

- Peroba Rosa (Aspisdosperma polyneuron), Class C30;

- Eucalipto Tereticornis (Eucalyptus tereticornis), Class C40;

- Canafístula (Cassia ferruginea), Class C50;

- Jatobá (Hymenaea stilbocarpa), Class C60.

Note that including species in classes stipulated by ABNT NBR 7190 [19] is based on the characteristic values of compression strength parallel to grain.

In this research, results of one set of twelve specimens (nominal dimensions $5 \mathrm{~cm} \times 5 \mathrm{~cm} \times 115 \mathrm{~cm}$ ) per species evaluated, obtained with the growth rings parallel to two opposite sides of specimens, were considered.

Each specimen was tested four times in static bending: two with force applied on LR plane and two in the plane LT. In all situations, specimens were initially tested according to the four point static bending model (Figure 1a), used by American Standard ASTM D 198 [29], with nominal span $105 \mathrm{~cm}\left(\mathrm{~L}_{1}\right)$, nominal height $5 \mathrm{~cm}$, obeying ratio $\mathrm{L}_{1} / \mathrm{h} \geq 21$ [20] ensuring that shear stress contribution to vertical displacements $(\delta)$ is negligible. All tests were carried out non-destructively, restricting displacement at the midpoint of specimens to $\delta_{1}=\mathrm{L}_{1} / 200$. In this case, it is ensured that the proportionality limit was not exceeded [19].

Once determined force $\left(\mathrm{F}_{1}\right)$, responsible for displacement $\mathrm{L}_{1} / 200$, and known specimens dimensions (height $[\mathrm{h}]$ and width [b] of cross section), these data are used in the equation of displacement for the above test structural model derived from the strength of materials (Equation 1), consisting of one equation with two unknown variables (E and $G)$. Thereafter, the supports were approximated, giving a useful second length $\left(\mathrm{L}_{2}\right)$ to the test piece $(70 \mathrm{~cm})$, and this was applied to a load $\left(F_{2}\right)$ from the midpoint of the beam (Figure 1b), according three points static bending model. By holding the value of the scale and load displacement $\delta_{2}=L_{2} / 200$ in the middle of the span of the structural model, these data were cast into Equation shifts from the strength of materials (Equation 2) providing a second equation in the variables $\mathrm{E}$ and $\mathrm{G}$.

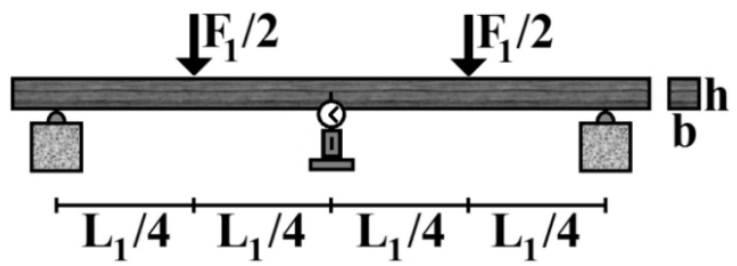

(a)

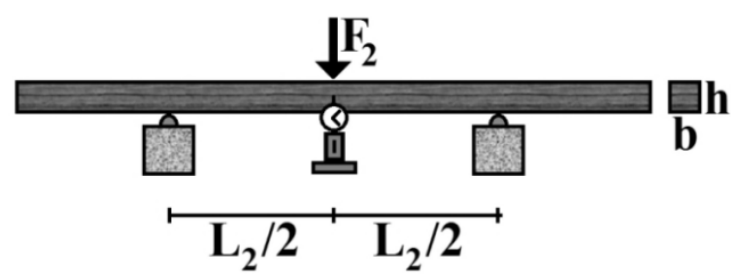

(b)

Figure 1. Four point (a) and three points (b) static bending tests

$$
\begin{gathered}
\delta_{1}=\frac{11 \cdot F_{1} \cdot L_{1}^{3}}{768 \cdot I} \cdot \frac{1}{E} \\
\delta_{2}=\frac{F_{2} \cdot L_{2}^{3}}{48 \cdot I} \cdot \frac{1}{E}+\frac{f_{S} \cdot F_{2} \cdot L_{2}}{4 \cdot A} \cdot \frac{1}{G}
\end{gathered}
$$

Solving Equations 1 and 2, both derived from four and three points bending tests, leads to values of longitudinal and shear modulus of elasticity, Equations 3 and 4, respectively. 


$$
\begin{gathered}
E=\frac{11 \cdot F_{1} \cdot L_{1}^{3}}{768 \cdot \delta_{1} \cdot I} \\
G=\frac{11 \cdot f_{s} \cdot F_{2} \cdot L_{2} \cdot F_{1} \cdot L_{1}^{3}}{4 \cdot A \cdot\left(11 \cdot F_{1} \cdot L_{1}{ }^{3} \cdot \delta_{2}-16 \cdot F_{2} \cdot L_{2}{ }^{3} \cdot \delta_{1}\right)}
\end{gathered}
$$

Note that cantilevers of the specimens in bending test do not influence deflections in region between supports to obtain $\mathrm{E}$ and $\mathrm{G}$ [18].

To evaluate equivalence between longitudinal moduli of elasticity $\left(E_{L R}\right.$ and $\left.E_{L T}\right)$ and between shear moduli $\left(G_{L R}\right.$ and $\mathrm{G}_{\mathrm{LT}}$ ), for each wood species, hypothesis testing at 5\% significance level $(\alpha)$ was assumed. In this case, null hypothesis $\left(\mathrm{H}_{0}\right)$ refers the equivalence of mean values of $\left(E_{L R} ; E_{L T}\right)$ and $\left(G_{L R}\right.$ and $\left.G_{L T}\right)$; non-equivalence between the means is the alternative hypothesis $\left(\mathrm{H}_{1}\right)$. $\mathrm{P}$-value higher than the significance level or presence of zero in confidence interval $(\mu)$ leads to accept $\mathrm{H}_{0}$, rejecting it otherwise.

In order to investigate equivalence between moduli of elasticity obtained in LT and LR directions, regardless of wood species used, longitudinal elastic modulus achieved at LR were divided by the corresponding values of longitudinal modulus of elasticity obtained by the LT plane $\left(\mathrm{E}_{\mathrm{LR}} / \mathrm{E}_{\mathrm{LT}}\right)$. The same procedure was taken to shear moduli $\left(\mathrm{G}_{\mathrm{LR}} / \mathrm{G}_{\mathrm{LT}}\right)$. Therefore, null hypothesis formulated in hypothesis testing $(\alpha=0.05)$ consisted of 1 be the average of values obtained, implying the equivalence between the values of modulus of elasticity, and different from 1 as alternative hypothesis (values of modules elasticity are not equivalent.) P-value greater than $5 \%$ implies accepting $\mathrm{H}_{0}$, rejecting it otherwise.

To validate hypothesis tests, Anderson-Darling normality test at the 5\% level of significance was applied. Null hypothesis was to assume normality for the modulus of elasticity values; and non-normality as the alternative hypothesis. P-value greater than 0.05 implies accepting $\mathrm{H}_{0}$, rejecting it otherwise.

In order to estimate shear modulus based on the values of longitudinal modulus of elasticity for any wood species, a model of linear regression by least squares was used. The significance and quality of fit were evaluated by analysis of variance (ANOVA) of the regression, the significance level of $5 \%$, having null hypothesis is the non-significance of the regression coefficients adjusted and the significance of the regression as alternative hypothesis. P-value less than the significance level implies rejecting the null hypothesis $\left(\mathrm{F}_{\text {calc }}>\right.$ $\mathrm{F}_{\mathrm{tab}}$ ), accepting it otherwise. Alternatively, as done in the research of Christoforo et al. (2013), the relationship between the modulus of elasticity $(E=\xi \cdot G)$ was evaluated with the use of Equation 7 (least squares), which consists in determining the best coefficients $(\xi)$.

$$
f(\xi)=\frac{1}{2} \cdot \sum_{i=1}^{n}\left(E_{i}-\xi \cdot G_{i}\right)^{2}
$$

\section{Results and Discussions}

Tables 1 and 2 present results of longitudinal modulus of elasticity and shear modulus, respectively, of the five wood species investigated; sample means $(\bar{x})$; coefficients of variation $(\mathrm{Cv})$; smallest (Min) and largest (Max) values found.

P-values of Anderson-Darling test for longitudinal modulus of elasticity ranged in interval 0.119 to 0.783 . Distributions of all variables investigated responses (P-value $>0.05$ ) are normal, validating the use of test hypothesis. Table 3 shows results of hypothesis testing between $\mathrm{E}$ and $\mathrm{G}$, for each wood species, with 21 degrees of freedom. Once P-values were superior to the significance level $5 \%$ or zero is present in confidence intervals found, it is possible to admit there is equivalence between $\mathrm{E}_{\mathrm{LR}} \times \mathrm{E}_{\mathrm{LT}}$ and $\mathrm{E}_{\mathrm{LR}} \times \mathrm{E}_{\mathrm{LT}}$ for all species considered.

For the ratio $\mathrm{E}_{\mathrm{LR}} / \mathrm{E}_{\mathrm{LT}}$, P-value from Anderson-Darling normality test was 0.188 , validating the adopted hypothesis. P-value and confidence interval for the investigated ratio were 0.752 and $0.9790 \leq \mu \leq 1.0289$, respectively. Thus, equivalence between the values of modulus of elasticity in directions LR and LT, independent of wood species, can be

\begin{tabular}{|c|c|c|c|c|c|c|}
\hline \multirow[b]{2}{*}{ Estat. } & \multicolumn{2}{|c|}{ Cedrinho } & \multicolumn{2}{|c|}{ Peroba Rosa } & \multicolumn{2}{|c|}{ Tereticornis } \\
\hline & $\mathbf{E}_{\mathrm{LR}}(\mathrm{MPa})$ & $\mathbf{E}_{\mathrm{LT}}(\mathrm{MPa})$ & $\mathrm{E}_{\mathrm{LR}}$ (MPa) & $\mathbf{E}_{\mathrm{LT}}(\mathrm{MPa})$ & $\mathrm{E}_{\mathrm{LR}}(\mathrm{MPa})$ & $\mathrm{E}_{\mathrm{LT}}(\mathrm{MPa})$ \\
\hline $\bar{x}$ & 8557 & 8434 & 12215 & 11879 & 11159 & 11691 \\
\hline$C v$ & 15 & 16 & 18 & 13 & 14 & 12 \\
\hline Min. & 6647 & 5974 & 9626 & 9510 & 8308 & 9801 \\
\hline Max. & 10978 & 10821 & 15332 & 13878 & 13118 & 14310 \\
\hline & \multicolumn{2}{|c|}{ Canafístula } & \multicolumn{2}{|c|}{ Jatobá } & & \\
\hline Estat. & $\mathbf{E}_{\mathrm{LR}}(\mathrm{MPa})$ & $\mathbf{E}_{\mathrm{LT}}(\mathrm{MPa})$ & $\mathrm{E}_{\mathrm{LR}}(\mathrm{MPa})$ & $\mathrm{E}_{\mathrm{LT}}(\mathrm{MPa})$ & & \\
\hline $\bar{x}$ & 14288 & 14466 & 18565 & 18298 & & \\
\hline$C v$ & 15 & 18 & 13 & 14 & & \\
\hline Min. & 11980 & 11789 & 14494 & 14897 & & \\
\hline Max. & 17342 & 18573 & 22567 & 23050 & & \\
\hline
\end{tabular}
assumed.

Table 1. Results of $E_{L R}$ and $E_{L T}$ 
Table 2. Results of $\mathrm{G}_{\mathrm{LR}}$ and $\mathrm{G}_{\mathrm{LT}}$

\begin{tabular}{|c|c|c|c|c|c|c|}
\hline \multirow[b]{2}{*}{ Estat. } & \multicolumn{2}{|c|}{ Cedrinho } & \multicolumn{2}{|c|}{ Peroba Rosa } & \multicolumn{2}{|c|}{ Tereticornis } \\
\hline & $\mathrm{G}_{\mathrm{LR}}(\mathrm{MPa})$ & $\mathrm{G}_{\mathrm{LT}}(\mathrm{MPa})$ & $\mathrm{G}_{\mathrm{LR}}(\mathrm{MPa})$ & $\mathrm{G}_{\mathrm{LT}}(\mathrm{MPa})$ & $\mathrm{G}_{\mathrm{LR}}(\mathrm{MPa})$ & $\mathrm{G}_{\mathrm{LT}}(\mathrm{MPa})$ \\
\hline $\bar{x}$ & 210 & 213 & 248 & 249 & 367 & 399 \\
\hline$C v$ & 15 & 18 & 17 & 17 & 17 & 16 \\
\hline Min. & 159 & 159 & 181 & 181 & 277 & 251 \\
\hline Max. & 263 & 284 & 308 & 303 & 509 & 481 \\
\hline \multicolumn{3}{|c|}{ Canafístula } & \multicolumn{2}{|c|}{ Jatobá } & & \\
\hline Estat. & $\mathrm{G}_{\mathrm{LR}}(\mathrm{MPa})$ & $\mathrm{G}_{\mathrm{LT}}(\mathrm{MPa})$ & $\mathrm{G}_{\mathrm{LR}}(\mathrm{MPa})$ & $\mathrm{G}_{\mathrm{LT}}(\mathrm{MPa})$ & & \\
\hline $\bar{x}$ & 425 & 414 & 458 & 466 & & \\
\hline$C v$ & 18 & 20 & 27 & 28 & & \\
\hline Min. & 287 & 284 & 306 & 296 & & \\
\hline Max. & 521 & 542 & 639 & 691 & & \\
\hline
\end{tabular}

Table 3. Results of hypothesis testing (E and G)

\begin{tabular}{clcc}
\hline Species & Relation & P-value & IC $(\boldsymbol{\mu})$ \\
\hline Cedrinho & $\mathrm{E}_{\mathrm{LT}} \times \mathrm{E}_{\mathrm{LR}}$ & 0,822 & $-996 \leq \mu \leq 1241$ \\
Peroba Rosa & $\mathrm{E}_{\mathrm{LT}} \times \mathrm{E}_{\mathrm{LR}}$ & 0,688 & $-1280 \leq \mu \leq 1953$ \\
Tereticornis & $\mathrm{E}_{\mathrm{LT}} \times \mathrm{E}_{\mathrm{LR}}$ & 0,385 & $-1777 \leq \mu \leq 714$ \\
Canafístula & $\mathrm{E}_{\mathrm{LT}} \times \mathrm{E}_{\mathrm{LR}}$ & 0,856 & $-2195 \leq \mu \leq 1838$ \\
Jatobá & $\mathrm{E}_{\mathrm{LT}} \times \mathrm{E}_{\mathrm{LR}}$ & 0,794 & $-1827 \leq \mu \leq 2360$ \\
Cedrinho & $\mathrm{G}_{\mathrm{LT}} \times \mathrm{G}_{\mathrm{LR}}$ & 0,873 & $-3,24 \leq \mu \leq 27,70$ \\
Peroba Rosa & $\mathrm{G}_{\mathrm{LT}} \times \mathrm{G}_{\mathrm{LR}}$ & 0,948 & $-37,90 \leq \mu \leq 35,60$ \\
Tereticornis & $\mathrm{G}_{\mathrm{LT}} \times \mathrm{G}_{\mathrm{LR}}$ & 0,214 & $-85,60 \leq \mu \leq 20,30$ \\
Canafístula & $\mathrm{G}_{\mathrm{LT}} \times \mathrm{G}_{\mathrm{LR}}$ & 0,740 & $-57,10 \leq \mu \leq 79,18$ \\
Jatobá & $\mathrm{G}_{\mathrm{LT}} \times \mathrm{G}_{\mathrm{LR}}$ & 0,879 & $-114,40 \leq \mu \leq 98,50$ \\
\hline
\end{tabular}

For the ratio $\mathrm{G}_{\mathrm{LR}} / \mathrm{G}_{\mathrm{LT}}$, P-value from Anderson-Darling normality test was 0.871 , validating the adopted hypothesis. P-value and confidence interval for the investigated ratio were 0.930 and $0.9545 \leq \mu \leq 1.0416$, respectively. As the case of $\mathrm{E}$, equivalence between shear modulus in directions LR and LT, regardless of wood species, can be assumed.

Figure 2 shows graph of the regression function $(G=0.0182 \cdot E+108.7)$ obtained from the regression model, with coefficient of determination $\mathrm{R}^{2}$ and adjusted P-value equal to 31.70 and 0.483 . Therefore, it has showed inefficiency and no significance of the estimating shear modulus by longitudinal modulus of elasticity.

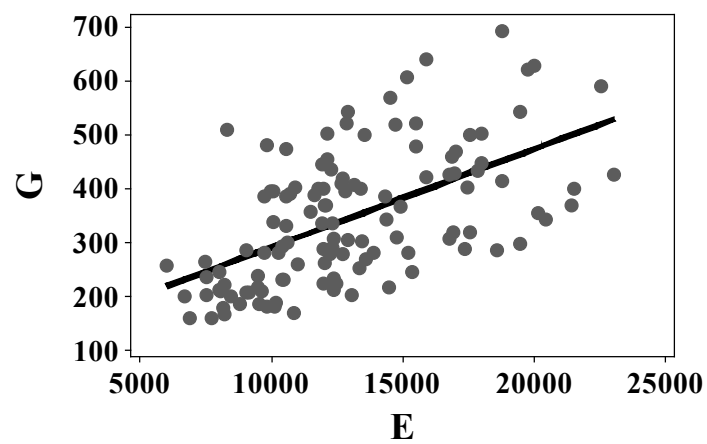

Figure 2. Linear regression: $\mathrm{G}$ as function of $\mathrm{E}$

From least squares model (Equation 7), coefficient $\xi$ for relation $(E=\xi \cdot G)$ was 35 . So, $G=E / 35$ differs widely from the ratio proposed by Brazilian Standard ABNT NBR 7190 [19]
$(G=E / 20)$.

\section{Conclusions}

Results of hypothesis tests between the modulus of elasticity $\mathrm{E}_{\mathrm{LR}}$ and $\mathrm{E}_{\mathrm{LT}}$ obtained based on static bending tests showed equivalence by species and for all species simultaneously.

Results of linear regression by least squares show it is not possible to estimate shear modulus $(G)$ by means of longitudinal modulus of elasticity $(\mathrm{E})$. The best coefficient obtained by least squares model for the mentioned relation was $35(\mathrm{G}=\mathrm{E} / 35), 75 \%$ higher than coefficient $(\mathrm{G}=\mathrm{E} / 20)$ established by the Brazilian Standard ABNT NBR 7190 [19]. This suggests the need of adjusting coefficient $E / G$ for the adequate design of timber structures.

\section{REFERENCES}

[1] Mateus, T. J. E. Bases para o dimensionamento de estruturas de madeira. Lisboa, LNEC, 436p, 1961.

[2] Karlsen, G. G. Wooden Structures. Moscou, Mir Publishers, $682 p, 1967$.

[3] Bodig, J.; Jayne, B. A. Mechanics of wood and wood composites. New York, Van Nostrand Reinhold Company, $712 \mathrm{p}, 1982$

[4] Ritter, M. A. Timber bridges. Forest Products Laboratory, Forest Service, Madison, USA, 1990.

[5] Calil Jr., C.; Rocco Lahr, F. A.; Dias, A. A. Dimensionamento de Elementos Estruturais de Madeira. Barueri, Editora Manole Ltda, 152p, 2003.

[6] Herzog, T; Natterer, J.; Schweitzer, R.; Votz, M.; Winter, W. Timber Construction Manual. Birkhäuser Ed. 385p, 2000.

[7] Christoforo, A. L.; Panzera, T. H.; Batista, F. B.; Borges, P. H. R.; Rocco Lahr, F. A. Numerical evaluation of the modulus of longitudinal elasticity in structural round timber elements of the Eucalyptus genus. Engenharia Agrícola (Online), v. 31, p. 1009-1016, 2011. 
[8] Ferro, F. S.; Icimoto, F. H.; Almeida, D. H.; Christoforo, A. L.; Rocco, F. A. L. Verification of Test Conditions to Determine the Compression Modulus of Elasticity of Wood. International Journal of Agriculture and Forestry, v. 3, p. 66-70, 2013.

[9] Icimoto, F. H.; Ferro, F. S.; Almeida, D. H.; Christoforo, A. L.; Rocco, F. A. L. Influence of the wood specimen position on calculus of the bending modulus of elasticity. International Journal of Materials Engineering, v. 3, p. 41-46, 2013.

[10] Braz, J. C. F.; Layber, R. B.; Lauro, C. H.; Christoforo, A. L.; Panzera, T. H.; Rocco, F. A. L.; Silva, V. R. V. Numerical Evaluation of the Mechanical Behavior of a Particulate Composite Material as Reinforcement in Timber Beams. International Journal of Composite Materials, v. 3, p. 83-91, 2013.

[11] Price, A. T. A mathematical discussion on the structure of wood in relation to its elastic properties. Philosophical Transactions of the Royal Society of London. Series A, 228:1-62, 1929.

[12] Schniewind, A. P. Transverse anisotropy of wood, Forest Products Journal., 9(10):350-359, 1959.

[13] Gillis, P. P. Orthotropic Elastic Constants of Wood, Wood Science and Technology, v.6, p. 138-156, Springer-Verlag, 1972.

[14] Holmberg, S.; Persson, K.; Petersson, H. Nonlinear mechanical behavior and analysis of wood and fibre materials. Computers and Structures, v.72, p. 459-480, Pergamon, 1999.

[15] Nairn, J. A. A Numerical Study of the Transverse Modulus of Wood as a Function of Grain Orientation and Properties. Wood Science \& Engineering, Oregon State University, p. 1-10, 2007.

[16] Ballarin, A. W.; Nogueira, M. Caracterização elástica da madeira de Eucalyptus citriodora. Cerne, v. 9, n. 1, p.66-80, 2003.

[17] Mascia, N. T.; Rocco Lahr, F. A. Remarks on orthotropic elastic models applied to wood, Materials Research, v. 9, n. 3, p. 301-310, 2006.

[18] Christoforo, A. L.; Filho, S. L. M. R.; Panzera, T. H.; Rocco Lahr, F. A. Metodologia para o cálculo dos módulos de elasticidade longitudinal e transversal em vigas de madeira de dimensões estruturais. Ciência Rural, v. 43, n.4, p. 610-615, 2013.

[19] Associação Brasileira de Normas Técnicas. NBR 7190 Projeto de estruturas de madeira. Rio de Janeiro 1997.

[20] Rocco Lahr, F. A. Sobre a determinação de propriedades de elasticidade da madeira. Tese (Doutor em Engenharia de Estruturas), Escola de Engenharia de São Carlos, Universidade de São Paulo, 221p, 1983.

[21] Bucur, V.; Archer, R. R. Elastic constants for wood by an ultrasonic method. Wood Science and Technology, v.18, p. 255-265, 1984

[22] Sandoz, J. L. Grading of construction timber by ultrasound. Wood Science and Techonolgy, v.23, p. 95-108, 1989.

[23] Ross, R. J.; Brashaw, B. K.; Pellerin, R. F. Nondestructive evaluation of wood. Forest Products Journal, Madison, US, v. 48, n. 1, p. 14-19, 1998.

[24] Gonzales, J. C.; Valle, A. T.; Costa, A. F. Estimativa das constantes elásticas da madeira por meio de ondas ultrassonoras. Cerne, v. 7, n. 2, p. 81-92, 2001.

[25] Yang, T.; Wang, S.; Lin, C.; Tsai, M. Evaluation of the mechanical properties of Douglas fir and Japanese cedar lumber and its structural glulam by nondestructive techniques. Construction and Building Materials, v. 22, p. 487-493. 2008.

[26] Gonçalves, R.; Trinca, A. J.; Cerri, D. G. Comparison of elastic constants of wood determined by ultrasonic wave propagation and static compression test. Wood and Fiber Science, v. 43, p. 64-75, 2011.

[27] Alves, R. C.; Carrasco, E. W. M. Estimativa de constantes de rigidez de madeiras tropicais ultra-duras orientadas nas três direções principais. Enciclopédia Biosfera, v. 9, n. 16, p. 1079-1086, 2013.

[28] Green, D. W.; Winandy, J. E.; Kretschmann, D. E. Mechanical properties of wood. USDA Forest Service, Forest Products Laboratory. General technical report FPL; GTR-113: p. 4.1-4.45, 1999.

[29] American Society for Testing and Materials (ASTM). Standard test method of static tests of lumber in structural sizes. ASTM D 198. Annual book of ASTM standards, v. 03.01. ASTM, West Conshohocken, Philadelphia, 1997. 